Bulletin of the Natural History Museum, 2013, 6: 55-64.

Received 12 Sep 2009; Accepted 15 Jan 2013.

DOI: $10.5937 /$ bnhmb1306055T

UDC: 594.3(497.16)

\title{
CONTRIBUTION TO THE KNOWLEDGE OF THE SLUGS (GASTROPODA: STYLOMMATOPHORA: LIMACIDAE AND MILACIDAE) FROM MONTENEGRO
}

\author{
BilJana TelebaK ${ }^{1}$, MiloJe BRAJKOVIĆ ${ }^{\dagger}{ }^{\dagger}$, SREĆKO ĆURČIĆ ${ }^{2}$ \\ ${ }^{1}$ Environmental Protection Agency of Montenegro, IV Proleterske 19, \\ 81000 Podgorica, Montenegro \\ ${ }^{2}$ Institute of Zoology, University of Belgrade - Faculty of Biology, \\ Studentski Trg 16, 11000 Belgrade, Serbia, e-mail: srecko@bio.bg.ac.rs
}

In this paper we have recorded five slug species of the genera Limax Linnaeus, Limacus Lehmann, and Tandonia Lessona \& Pollonera for the first time in Montenegro: Limax graecus Simroth, 1889, Limacus flavus (Linnaeus, 1758), Tandonia kusceri (Wagner, 1931), T. budapestensis (Hazay, 1880), and T. lagostana (Wagner, 1940). Representatives of the genus Limacus are registered for the first time for the country. The slug material was collected from northern, central, and southern Montenegro.

Key words: Gastropoda, slugs, new species, Limax, Limacus, Tandonia, Montenegro

\section{INTRODUCTION}

Among snails (gastropods), slugs are the least studied group in Montenegro. Therefore, it is expected that some novelties will appear in the systematic investigations into this group from the region. Slugs are very sensitive animals with no special protection against external factors, especially heat, unlike snails with their shells. They have special need for humidity and hidden places during sunny periods. 
The first information on slug fauna in Montenegro was given by well-known malacologist Wohlberedt (1907). However, these data were rather scarce since the author cited studies given by previous scientists that had gathered the slugs. The genus Limax Linnaeus is present in Montenegro with four species: Limax maximus Linnaeus, 1758, L. wohlberedti Simroth, 1900, L. conemenosi Boettger, 1882, and L. illyricus Simroth, 1907 (Van Regteren Altena 1975, Jovanović 1995, Wiktor 1996, 1997). No species of the genus Limacus Lehmann had been registered in Montenegro at this point. The genus Tandonia Lessona \& Pollonera comprises four species in Montenegrin fauna: Tandonia albanica (Soós, 1924), T. cavicola (Simroth, 1916), T. reuleauxi (Clessin, 1887), and T. sowerbyi (Férussac, 1823) (Wiktor 1996, 1997). Altogether 27 slug species are registered from Montenegrin territory, while a lesser number of slug species is reported from most other Balkan countries (Serbia and Macedonia - 24 each; Albania and Bosnia and Herzegovina - 22 each) (Simroth 1907, Wohlberedt 1907, 1909, Wiktor 1982, 1983, 1987, 1996, 1997, 2001, Bole 1984, Karaman 2006, Fehér \& Erőss 2009). Within ex Yugoslav countries, only the slug faunas of Croatia (43) and Slovenia (28) are richer in species than the Montenegrin (Wiktor 1982, 1996, 1997, Štamol 2010, Bank 2011).

\section{MATERIAL AND METHODS}

The slugs were collected manually and individually during 2000, 2001, 2004, and 2006 by the first author of the paper. After that, the material was first transferred into distilled water in tightly-sealed glass jars. After death the specimens from the samples were removed into $70 \%$ ethanol, in which the snails remain permanently. The material from four localities was identified according to Wiktor $(1996,1997)$. The newest systematics and nomenclature were used (Bank 2013). The slug samples are kept in the malacological collection of the Environmental Protection Agency of Montenegro in Podgorica.

All results were summarized and analyzed with respect to diagnostic characters, genital structure features, ecology, and distribution of the taxa listed.

\section{RESULTS AND DISCUSSION}

During the period 2000-2006 altogether five species of slugs belonging to three genera and two families were recorded from Berane, Bijelo Polje, Podgorica, and Vranjina (northern, central, and southern Montenegro). 
These are the first findings of the taxa for Montenegro. Representatives of the genus Limacus are evident for the first time in Montenegro as well.

The registered taxa are listed below and their important genital features are illustrated (Figs. 1-5).

\section{Order PULMONATA \\ Suborder STYLOMMATOPHORA \\ Superfamily LIMACOIDEA \\ Family LIMACIDAE}

Genus Limax Linnaeus, 1758

Limax graecus Simroth, 1889

Examined material: town of Berane, northern Montenegro, 29.10.2000, one specimen, collected by B. Telebak.

Diagnostic characters: The slug reached up to $95 \mathrm{~mm}$ in length, $23 \mathrm{~mm}$ in width, up to $35 \mathrm{~mm}$ in mantle length. Skin sculpture delicate (19-25 wrinkles between the median line and pneumostome). Coloration different,

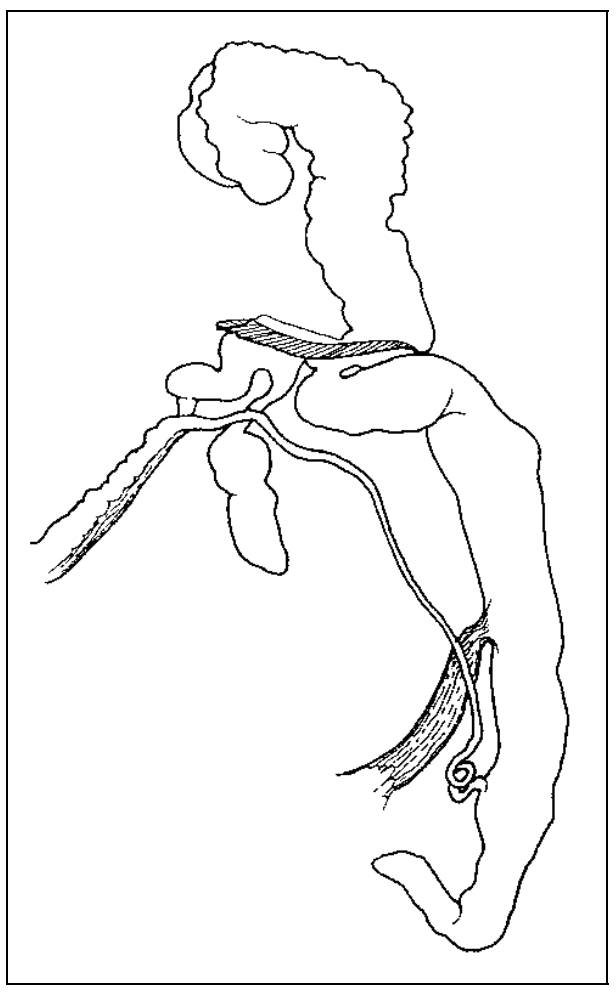

Fig. 1. - Copulatory organs of Limax graecus Simroth, 1889 (after Wiktor, 1996). from pinkish-creamy, through greyish and brownish to entirely black. Apart from unicolored forms, the dark-spotted specimens or the dark ones with light spotting are also found. The light forms occur in warmer habitats, while in mountains, at considerable heights, the slugs are dark in color. It is not possible to identify the slug on the basis of its coloration. It is worth mentioning, however, that its keel is of the same color as the rest of the back, which is a feature typical of some species of the genus. Sole unicolored, pale. Mucus colorless.

Genitalia (Fig. 1): Penis tubular, vermiform, irregularly bent or coiled, as long as appr. 2/3 of the body length or even longer. Musculus retractor penis inserted at ca. half penis length. Vas deferens connected to penis laterally, but more posteriorly. In mature specimens blind part of penis is in the 
shape of a narrowing, crescent structure, which is often strongly bent or curved. A longitudinal fold is situated inside the part of the penis (Wiktor 1996).

Ecology: The slug occurs in both deciduous and mixed forests. Most often, especially at night, it is found on tree trunks. It is also frequent in rocky areas, where it crawls up rocks and hides in crevices. In mountains the species was collected up to $1000 \mathrm{~m}$ a.s.l.

Distribution: Balkan endemic. The species inhabits continental Greece with Peloponessus and Euboea and Kythira Islands (Wiktor 2001). In Bulgaria it was found in the south up to Mt. Balkan. In the east it reaches the coast of the Black Sea (Wiktor 1983). In the former Yugoslavia it has been registered in Macedonia (FYROM) and Serbia (only at one locality) (Bank 2011).

Genus Limacus Lehmann, 1864

Limacus flavus (Linnaeus, 1758)

Examined material: city of Podgorica, central Montenegro, 14.03.2001 and 20.05.2006, three specimens, collected by B. Telebak.

Diagnostic characters: Body of live specimens up to $120 \mathrm{~mm}$ long, after preservation the length $80 \mathrm{~mm}$, width $19 \mathrm{~mm}$, mantle length $23 \mathrm{~mm}$. General body coloration olive, grey-greenish, grey-yellowish, or grey--orange. Coloration unevenly dark, and light spotting occurs alternatingly, or there are lighter spots on a darker background. Back and only a part of the sides darker in color. Above its sole a light stripe. Sole unicolored, pale, creamyyellowish. Head and tentacles black or blackish. Mucus yellow or orange, transparent, and watery.

Genitalia (Fig. 2): Spermoviduct short. A huge part of vas deferens surrounded by prostate. The free oviduct long. Vas deferens opens into penis apically, but asymmetrically. Penis cylindrical, as long as $1 / 6$ of the body length, bent, S- or E-formed. Spermatheca oval, with a short duct connected with enlarged anterior oviduct part. Oviduct mostly tubular, but anteriorly abruptly broadened before the connection with spermatheca duct. Atrium very short (Wiktor 1996).

Ecology: The original requirements of this slug are hardly known. It is probably a species of forests and lowlands. It prefers highly degraded cultivations, cellars, and vegetable storage places. The slug hides under stones, in crevices, tree holes, etc. It is often found in the neighborhood of wells and in other places moistened by water, frequent also in towns, even of dense structure, in dairies, fruit and vegetable warehouses, etc.

Distribution: The primordial distribution range of this species was probably in SE Europe and Asia Minor (Wiktor 1996, 1997). At present, as 
a synanthrope, it is found almost throughout Europe. It has been introduced into Africa, Australia, and oceanic islands.

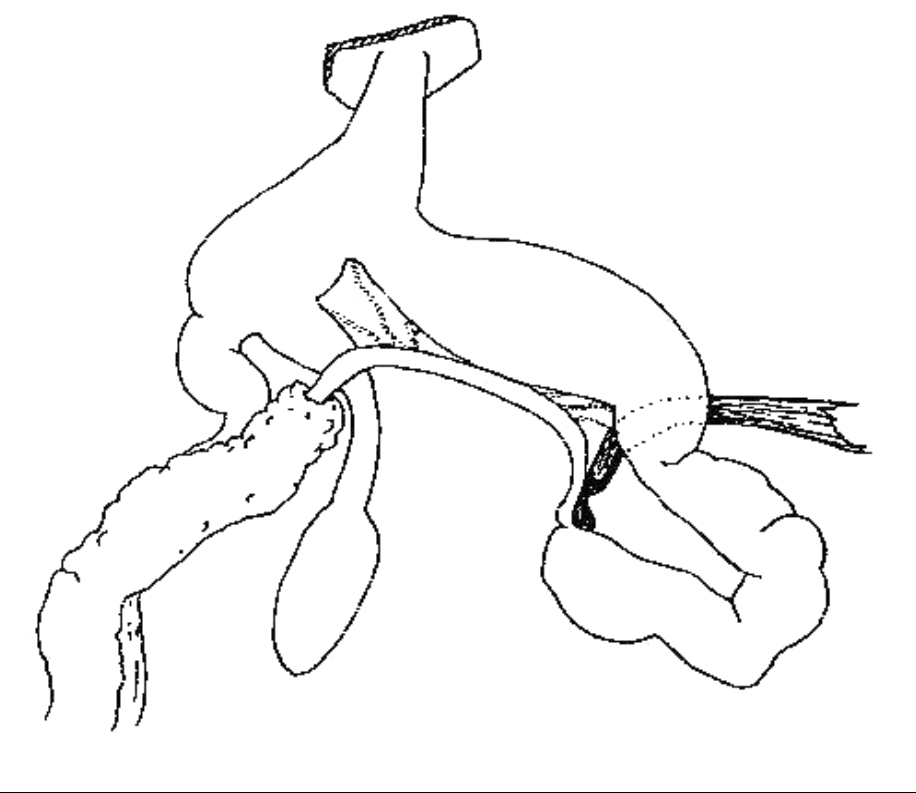

Fig. 2. - Copulatory organs of Limacus flavus (Linnaeus, 1758) (after Wiktor, 1996).

\section{Superfamily PARMACELLOIDEA}

Family MILACIDAE

Genus Tandonia Lessona \& Pollonera, 1882

Tandonia kusceri (Wagner, 1931)

Examined material: towns of Berane and Bijelo Polje, northern Montenegro, 24.10.2000 and 30.10.2000, two specimens, collected by B. Telebak.

Diagnostic characters: Body length up to $65 \mathrm{~mm}$, width $15 \mathrm{~mm}$, mantle length $20 \mathrm{~mm}$. Large specimens may stretch up to $100 \mathrm{~mm}$ when crawling. Keel quite distinct in live slugs. After preservation it may become poorly detectable. Coloration of live slugs pink-brown or ash grey-pink, with many small blackish spots of diffuse edges. Keel always pale, without spots, owing to which it contrasts with a slightly darker back. Sole mucky creamy. The hue of coloration, as well as the type of its pattern widely vary, even within the same population. Mucus thick, colorless. When the slug is irritated, an opaque milky-white secretion appears on its whole body. 
Genitalia (Fig. 3): Vas deferens very long, thin, coiled, opens apically and symmetrically to epiphallus. Epiphallus tubular, occasionally inconspicuously widened medially, very long and coiled, 5-6 times as long as penis. A slight constriction occurs on the border between epiphallus and penis. Anterior part of penis spherically distended, while posterior one cylindrical or club-like. Musculus retractor penis very thin, attached in the constriction between epiphallus and penis. Oviduct straight, elongated, and tubular. Spermatheca spherical, with thick and tubular duct. Vagina short, but recognizable. Accessory glands connected by thin ducts to vagina. Atrium very short (Wiktor 1996).

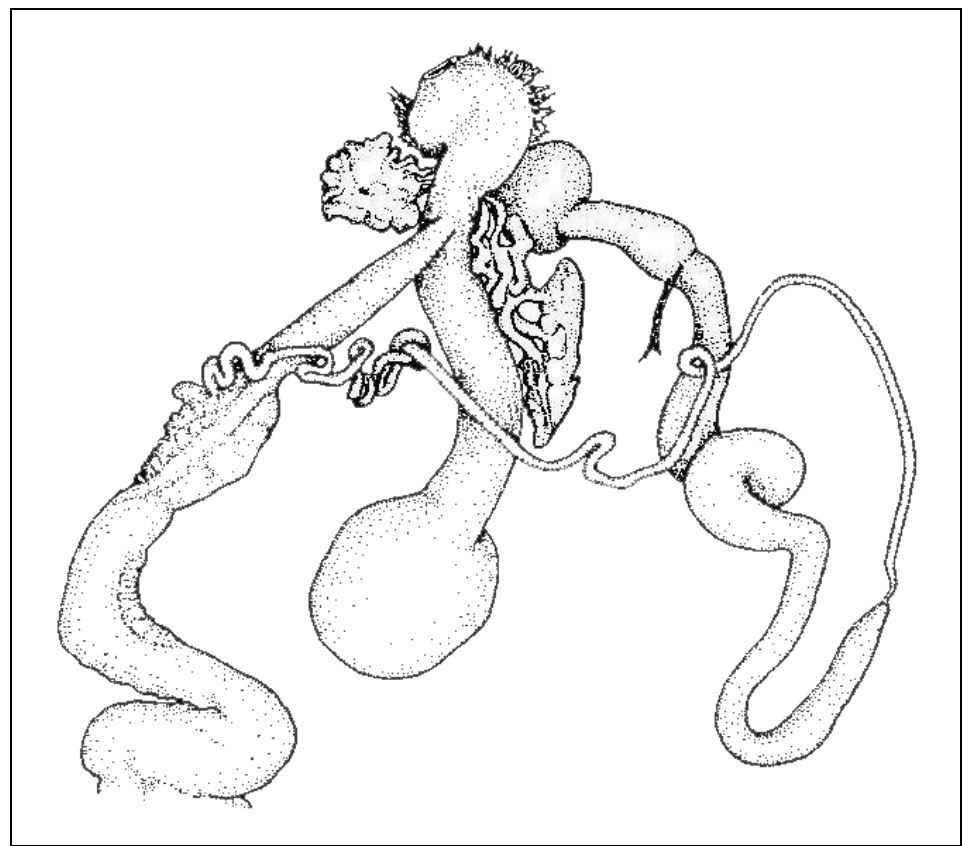

Fig. 3. - Copulatory organs of Tandonia kusceri (Wagner, 1931) (after Wiktor, 1996).

Ecology: The species of a great ecological tolerance. It occurs in environments of different humidity, in bushes, thickets, forests, and open biotopes, most willingly among rubble. Most often it is very abundant. It has a clear predisposition towards synanthropization. In mountains it reaches $1250 \mathrm{~m}$ a.s.l.

Distribution: Balkan endemic. The species inhabits mainly Bulgaria and Romania (Dobruja), and is also recorded from Turkey and Ukraine (Odessa) (Wiktor 1983). In the area of the former Yugoslavia it seems to be indigenous only to Serbia, Macedonia (FYROM), and Croatia, and particularly inhabits the regions bordering Bulgaria (Štamol 2010, Bank 2011). 
Tandonia budapestensis (Hazay, 1880)

Examined material: towns of Berane and Bijelo Polje, northern Montenegro, 24.10.2000 and 30.10.2000, two specimens, collected by B. Telebak.

Diagnostic characters: Body length of fully stretched live specimens up to $70 \mathrm{~mm}$, width $5 \mathrm{~mm}$, mantle length $11 \mathrm{~mm}$. General coloration blackish-chocolate. Skin covered with a blurred, darker pattern composed of blackish dots scattered over a creamy or orange background and forming a close reticulum. A dark pigment, present also on the mantle, produces indistinct dark streaks at sides. Head blackish. Sole orange or ashen. During preservation alcohol rinses away yellow and orange hues and the specimens become more ashen or blackish. Mucus thick, transparent. After irritation the slug secretes an opaque milky liquid.

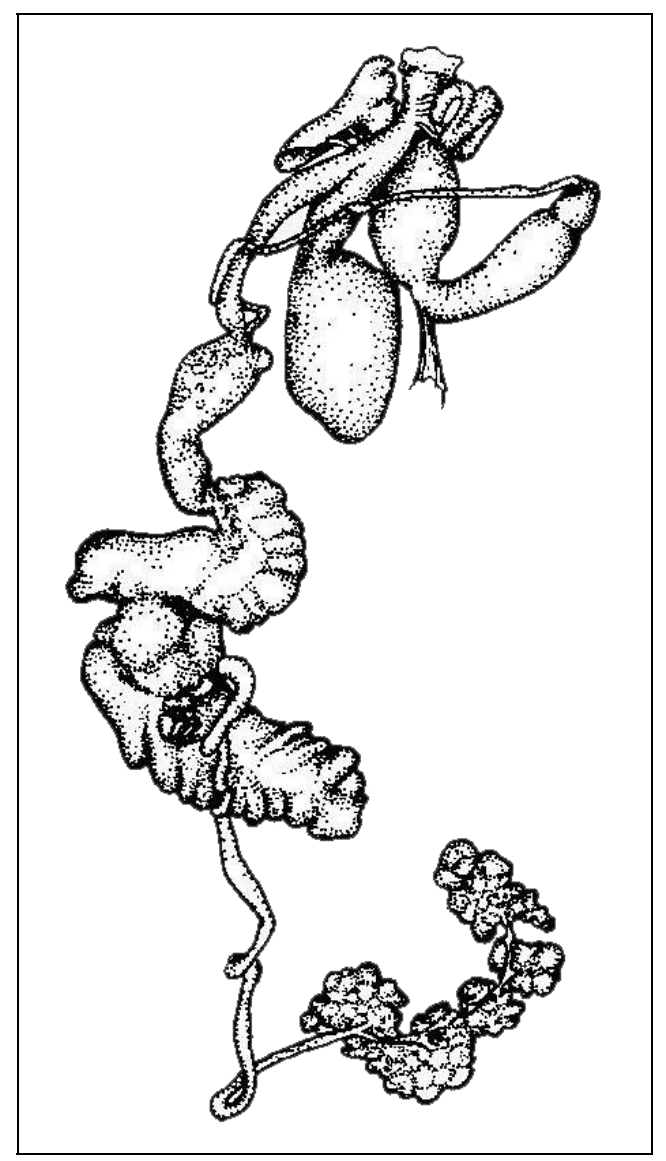

Fig. 4. - Copulatory organs of Tandonia budapestensis (Hazay, 1880) (after Wiktor, 1996).
Genitalia (Fig. 4): Vas deferens thin, asymmetrically opening at the epiphallus posterior section. Epiphallus claviform or cylindrical, as long as penis or somewhat longer. Penis usually somewhat rounded, broader than epiphallus. Musculus retractor penis developed. A small simple papilla situated inside the penis. Spermatheca oval or almost cylindrical, with a thick duct. Oviduct wide, pipe-like, while vagina very short. Lobe-like accessory glands connected to vagina by several thin ducts. Atrium tubular, short (Wiktor 1987).

Ecology: Eurytopic species, most often occurring as a synanthrope.

Distribution: The species is widely spread over the globe. Within Europe it inhabits almost the whole of southern Europe and part of central and western Europe (Wiktor 1996, 1997, Bank 2011). 
Tandonia lagostana (Wagner, 1940)

Examined material: village of Vranjina, near Bar, southern Montenegro, 2004, two specimens, collected by B. Telebak.

Diagnostic characters: The species was described on the basis of analysis of a juvenile specimen. Large slug, $70 \mathrm{~mm}$ long (although it was not mature yet), 17 $\mathrm{mm}$ wide, mantle length 22 $\mathrm{mm}$. Coloration reddish-ochreous, with a darker, brownish-violet back. Sides downwards gradually paler, but the dark pigment is accumulated in the skin grooves producing a reticulum. Information on mucus and spermatophore is lacking.

Genitalia (Fig. 5): Vas deferens opens apically, almost symmetrically to epiphallus. Epiphallus cone-like, cylindrical, coiled spirally. Penis rounded. Oviduct elongated, tubiform. Spermatheca long, oval, while its duct very short. Accessory glands not observed. Atrium very short, tubiform (Wiktor 1987).

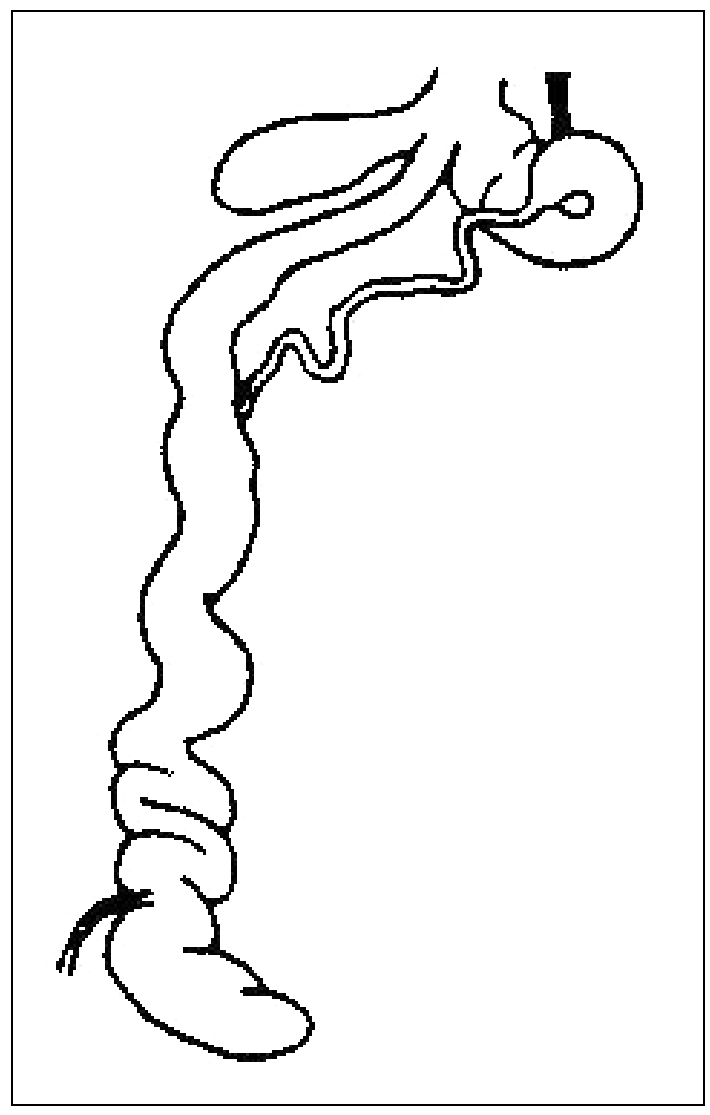

Fig. 5. - Copulatory organs of Tandonia lagostana (Wagner, 1940) (after Wiktor, 1987).

Ecology: Unknown.

Distribution: Balkan endemic (Croatia and Montenegro) (Štamol 2010, present study).

\section{CONCLUSIONS}

The slugs are insufficiently studied in Montenegro so far. The small number of published papers on these gastropods from the Balkans supports this opinion. This paper presents data on five new slug species for the fauna 
of this country collected from northern, central, and southern Montenegro. These species are the following: Limax graecus, Limacus flavus, Tandonia kusceri, T. budapestensis, and T. lagostana. The mentioned species belong to the genera Limax, Limacus (family Limacidae), and Tandonia (family Milacidae). Furthermore, representatives of the genus Limacus are registered for the first time for Montenegro. It is expected that some novelties will appear in the systematic investigations on this group from the region. The taxa registered herein as either new to the fauna of Montenegro or endemic to the Balkan Peninsula indicate that this list is far from complete. Therefore, much more remains to be done before we can say that the slugs of Montenegro and its surroundings are sufficiently known.

Acknowledgments. This study is financially supported by the Serbian Ministry of Education, Science, and Technological Development (Grant No. 173038).

\section{REFERENCES}

Bank, R. A. (2011): Checklist of the land and freshwater Gastropoda of Albania and former Yugoslavia. In: Anonymous (ed.): Fauna Europaea Project: $59 \mathrm{pp}$ (on-line form). [http://www.nmbe.unibe.ch/sites/default/files/uploads/pubinv/ fauna_europaea_-_gastropoda_of_albania_former_yugoslavia.pdf] (updated July 2011$)$

Bank, R. A. (ed.) (2013): Fauna Europaea. Mollusca: Gastropoda. Fauna Europaea version 2.6.2. [http://www.faunaeur.org/] (updated August 2013)

Bole, J. (1984): Mehkužci (Mollusca: Gastropoda et Bivalvia). In: Nonveiller, G. (ed.): Fauna Durmitora, Posebna izdanja 18, Odjeljenje prirodnih nauka 11 1: 363-394. - Crnogorska akademija nauka i umjetnosti, Titograd. [In Slovenian]

Fehér, Z., Erőss, Z. P. (2009): Checklist of the Albanian mollusc fauna. - Schriften zur Malakozoologie aus dem Haus der Natur - Cismar 25: 22-38.

Karaman, B. J. (2006): Former investigations of the fauna of snails (Mollusca, Gastropoda) in Bosnia \& Herzegovina. - Natura Montenegrina 5: 55-66.

Jovanović, B. (1995): Diverzitet puževa (Gastropoda, Mollusca) Jugoslavije sa pregledom vrsta od međunarodnog značaja. In: Stevanović, V., Vasić, V. (eds): Biodiverzitet Jugoslavije sa pregledom vrsta od međunarodnog značaja: 291-293. - Biološki fakultet \& Ecolibri, Beograd. [In Serbian]

Simroth, H. (1907): O puževima golušavcima Crne Gore. - Glasnik Zemaljskog muzeja Bosne i Hercegovine 19(4): 11-21. [In Serbian]

Štamol, V. (2010): A list of the land snails (Mollusca: Gastropoda) of Croatia, with recommendations for their Croatian names. - Natura Croatica 19(1): 1-76.

Van Regteren Altena, C. O. (1975): Notes on land slugs. 24. Redescription of Limax wohlberedti Simroth and Milax reuleauxi (Clessin) from Crna Gora (= Montenegro). - Basteria 39: 15-22. 
Wiktor, A. (1982): Contributions to the knowledge of the slugs of Yugoslavia (Arionidae, Milacidae, Limacidae, Agriolimacidae - Gastropoda, Pulmonata). - Annales Zoologici 36: 445-489.

Wiktor, A. (1983): The slugs of Bulgaria (Arionidae, Milacidae, Limacidae, Agriolimacidae - Gastropoda, Stylommatophora). - Annales Zoologici 37: 71-206.

Wiktor, A. (1987): Milacidae (Gastropoda, Pulmonata) - systematic monograph. - Annales Zoologici 41: 153-319.

Wiktor, A. (1996): The slugs of the former Yugoslavia (Gastropoda terrestria nuda - Arionidae, Milacidae, Limacidae, Agriolimacidae). - Annales Zoologici 46: 1110.

Wiktor, A. (1997): Endemism of slugs within the Balkan Peninsula and adjacent islands (Gastropoda: Pulmonata: Arionidae, Milacidae, Limacidae, Agriolimacidae). - Genus 8: 205-221.

Wiktor, A. (2001): The slugs of Greece (Arionidae, Milacidae, Limacidae, Agriolimacidae - Gastropoda, Stylommatophora). In: Anonymous (ed.): Fauna Graeciae 8: 1-241. - Natural History Museum of Crete \& Hellenic Zoological Society, Heraklion.

Wohlberedt, O. (1907): Kopneni mekušci Crne Gore (prilozi fauni Crne Gore). - Glasnik Zemaljskog muzeja Bosne i Hercegovine 19(4): 499-574. [In Serbian]

Wohlberedt, O. (1909): Zur Fauna Montenegros und Nordalbaniens (Mollusken, Käfer, Isopoden, Chilopoden, Diplopoden). - Wissenschaftliche Mitteilungen aus Bosnien und der Herzegowina 11: 585-711.

\title{
ПРИЛОГ ПОЗНАВАњУ ПУЖЕВА ГОЛАЋА (GASTRОРОDА: STYLOMMATOPHORA: LIMACIDAE И MILACIDAE) ЦРНЕ ГOРЕ
}

\author{
БИљАНА ТЕЛЕБАК, МИЛОЈЕ БРАЈКОВИЋ ${ }^{\dagger}$, СРЕЋКО ЋУРЧИЋ
}

На територији Црне Горе први пут су евидентирани представници пет врста пужева голаћа: Limax graecus Simroth, 1889, Limacus flavus (Linnaeus, 1758), Tandonia kusceri (Wagner, 1931), T. budapestensis (Hazay, 1880) и T. lagostana (Wagner, 1940). Пужеви голаћи сакупљени су на локалитетима северног, централног и јужног дела земље. 